\title{
急性心筋梗塞の治療亡予後
}

\section{虚血性心疾患 の成因と治療}

米国の1987年の集計では，冠動脈疾患と診断さ れた患者は 700 万例, 急性心筋梗塞 125 万例, 入院 患者は75万例，同年の冠動脈疾患による死亡は50 万件であった。我が国では急性心筋梗塞は約 5 万 人とされるが,東京都では年間1000人が CCUネッ トワークの病院に入院しているに過ぎず，多くの 症例は CCUに入院していないと考えられる。全世 界では毎年150 200万人が急性心筋梗塞で入院す るとされる。

CCUの普及により院内死亡率は10数\%に減少し たが，再灌流療法の実施によりその死亡率はさら に7〜8\%に低下した（血栓溶解療法により $25 \%$ 減少)。その主たる原因は梗塞責任冠動脈の再開通 により梗塞サイズの縮小と合併症が減少したこと による。ここでは，血栓溶解療法を中心にした治 療および心筋梗塞の予後について述べる。

\section{急性心筋梗塞の病態}

冠動脈のスパズムが原因で，心筋梗塞に至るこ ともあるが，通常は何らかの機転で冠動脈粥腫に 破綻あるいは出血を生じて，血管内皮が損傷され， 内腔が急激に閉塞されることによる。血管内皮は 血小板やトロンビンの粘着・凝集に対し防御的に 作用しているが，内皮が傷害されるとこれらの防 御機構が破壊されるため, 血栓が形成, 成長する。 血栓は成長と同時に溶解作用も受け，血管傷害部 位が修復されると，血栓は縮小傾向を示し，梗塞 発症後 24 時間後には完全閉塞は約 6 割に減少する.
心筋の壊死は閉塞時間の延長とともに心内膜側よ り外膜側に波状的に拡大していく。

\section{梗塞急性期の治療}

心筋梗塞による死亡率は梗塞発症早期に高く, 時間の経過とともに漸減する。したがって，梗塞 発症時には，その場に居合わせたバイスタンダー が心肺蘇生法 (CPR) を有効に行うことが重要で ある、CCUのある病院に搬送すれば，必要に応じ て advanced CPR を行い，安静，酸素吸入，静脈 路の確保, ECG モニターが可能である. 次いで, 不整脈治療とともに，再灌流療法による梗塞サイ ズの縮小に務める。なお，急性期の $\beta$ 遮断薬 ${ }^{11}$ ，心 不全を有する例では ACE 阻害薬の有用性が明らか にされている2).

\section{血栓溶解薬とその有効性}

我が国では, urokinase (UK), t-PA (tissue plasminogen activator) が静注法として用いられ ており，近々pro-UKの静注も使用できるようにな るが, 欧米では, streptokinase (SK) と t-PAが 主で, さらにAPSAC (anisoylated plasminogen activator complex）が用いられている.SKは安 価であるものの，抗原性があり，また早期の溶解 率は $\mathrm{t}-\mathrm{PA}$ などに比べ低率で, UK と同様に血栓特 異性がない. UK は抗原性がない点でSKに優る。 t-PA は血栓特異性が高く,血栓溶解率が優れてお ク，抗原性もない。しかし高価で，また血中半減

[key words] 急性心筋梗塞症，血栓溶解療法，経皮的冠動脈形成術，予後 
期が短いために大量投与を必要とし，臨床的な使 用量になると全身線溶能が充進して出血傾向が明 らかとなる.pro-UKも fibrin 特異性が高く, 抗原 性はなく，血栓溶解能に優れているが，大量投与 では出血傾向が出現する。

UK96万単位あるいは SK150万単位の冠動脈内 注入で $60 \sim 70 \%$ 症例に再開通が得られる。冠動 脈血注入療法では，梗塞冠血管をはじめ他の冠動 脈病変を知ることができるため，血栓溶解療法不 成功の場合には，ただちに他の侵襲的治療に移行 できるメリットがある。また全身投与に比べて投 与量が少ないため, 合併症を抑えることができる。 一方，シネアンギオ装置と熟練したカテーテル。 チームが必要なうえ，投与開始が約 1 時間遅くな るデメリットを有する。

UK を静脈内投与すると,再開通率は約 $50 \%$ と低 い. UK 投与量を120～188万単位に増量すると再開 通率は高まるが，穿刺部位などからの出血傾向が 顕著となる。一方, t-PA や pro-UK の静脈注入に よる再開通率は70～80\%である。

\section{再灌流の time window}

側副血行や梗塞前狭心症の存在（preconditioning）は，梗塞サイズの縮小に役立つ一方，血圧や 心拍数の増加は梗塞サイズを拡大すると考之られ る.

閉塞血管の再開通により梗塞サイズ縮小が可能 になる時間帯（time window）がどの程度かは前 述の種々の因子などにより修飾されるが，通常は 6 時間以内とされている ${ }^{3)}$.したがって，徐々に進 行する血栓の自然溶解を待っていたのでは遅すぎ て梗塞サイズの縮小は期待できない. 発症後 6 ～24 時間の例を t-PA で治療した場合, 左室拡張末期容 量が有意に小さくなるという4)。一般に, ISIS-2 以 外の試験では，12時間以後に再灌流を行っても予 後改善はみられないが，心機能，とくに左室の remodelingの抑制には有効としている5゙.すなわち, 左室は梗塞後次第に梗塞領域が拡張，菲薄化して 心室腔は拡大, 非梗塞領域は代償性肥大を示すが, 梗塞責任動脈が開存しているとリモデリングが軽 減するとされる。

\section{open artery hypothesis と再開通の程度}

血栓溶解療法が成功すれば，梗塞サイズが縮小 し，予後が改善するとされる (open artery hypothesis).これまでの成績によると，1 カ月の死亡率は 血检溶解療法施行群の $11.6 \%$ から非施行群の 8.7 \%へと減少し，冠動脈再開通成功群では閉塞の例 と比へ，院内死亡率は著しく改善する $(32.1 \%$ 対 $2.0 \%)^{6}$.

ところで, SKよりも t-PAの方が再開通が早く, 再開通率も高いが，退院時ないし 1 力月後の予後 には差がなくなるとの成績があり，“open artery hypothesis”に対し疑問が出された.GUSTOの成
図 1 GUSTO 試験 \4 治療群におけ る死亡率の経時的推移

t-PA 初期增量群 (Accel t-PA) の死亡率改善は24時間ですでに 認められ，その効果は少なくと も30日まで持続している。 iv = 静注, $\mathrm{sc}=$ 皮下注

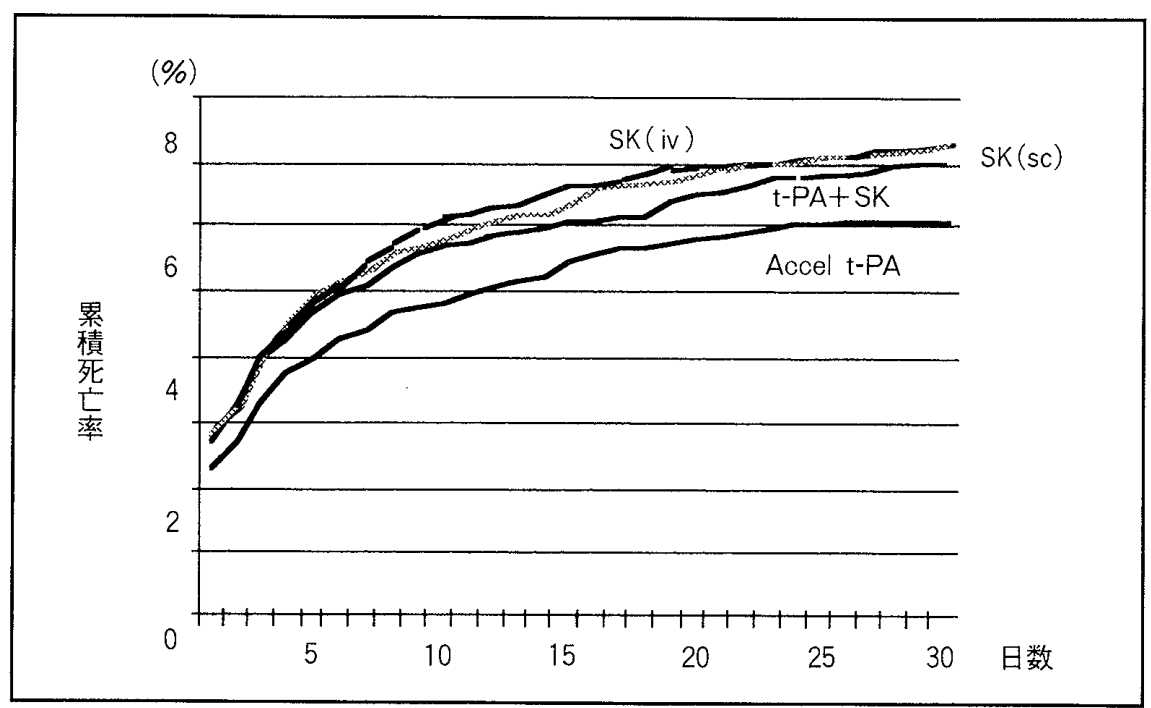

日本循環器学全尃門医䵽，循環器専門医第 4 巻第 1 号 
図 2 GUSTO 試験： 4 治療群におけ る治療開始 90 分後の冠動脈開通 度

$\mathrm{t}-\mathrm{PA}$ 初期増量群 (Accel t-PA) において TIMI 3 度の再開通率 が最も良好であった。

$\mathrm{Hep}=$ パリン, iv=静注, $\mathrm{sc}=$ 皮下注

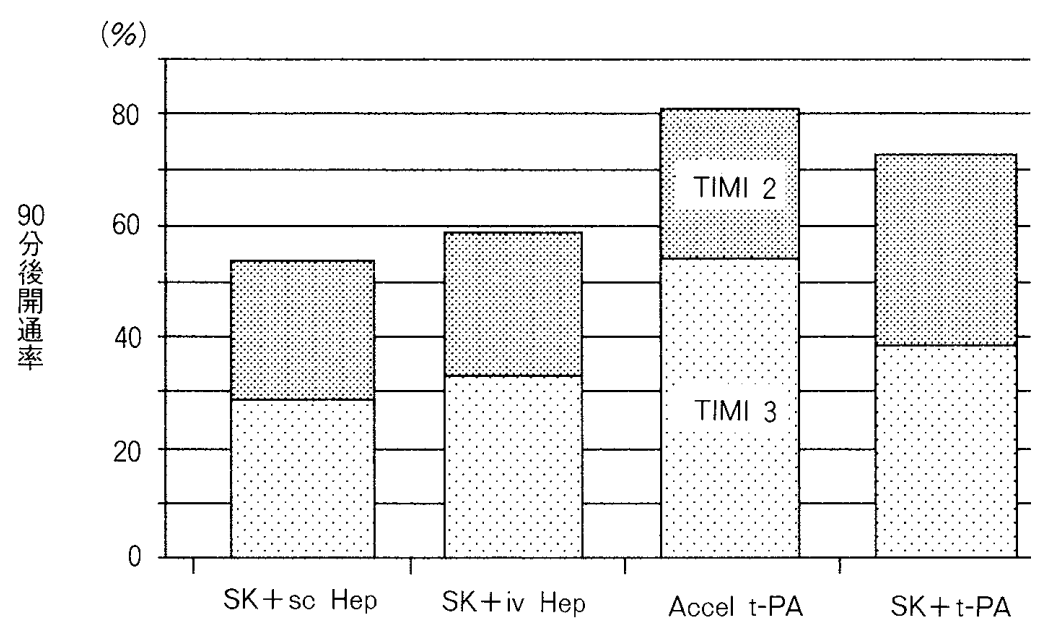

\section{(\%)}

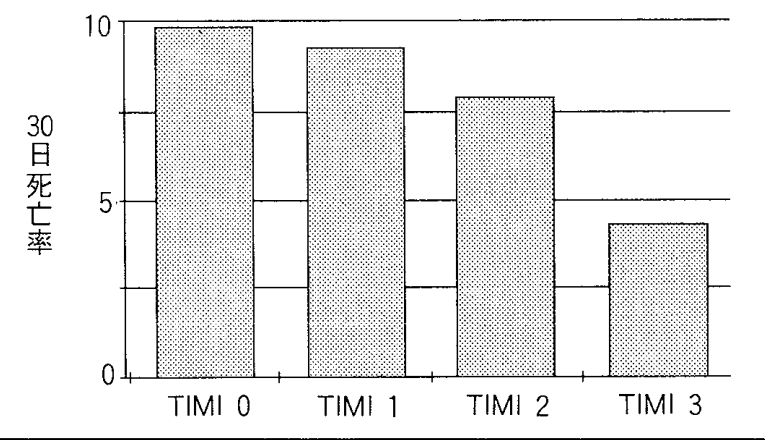

図 3 GUSTO 試験：TIMI 分類による再開通度と30日死 亡率の関係

開通が良好であれば死亡率が減少するが, TIMI 3 度で有意に低值となっている。

績7)では，t-PAによる死亡率滅少効果は24時間で すでにみられ(図 1)，それには治療開始後90分の 再開通率 (TIMI 2 度 $27 \%$, TIMI 3 度 $54 \%$, 合 計 $81 \%$ ；図 2）が関与しており，30日後の死亡率 は TIMI 2 度の7.9\%に対し, TIMI 3 度では $4.3 \%$

(図 3 ) と, “early” open artery が重要であると している.すなわち, TIMI 2 度の再開通は梗塞サ イズの縮小に不十分で8),そのような例には PTCA (percutaneous transluminal coronary angioplasty）を施行すれば壁運動が改善すると報告され ている9．なお， TIMI 分類 0 度は全く再疎通なし， 1 度は造影剂が血栓の中にしみ込むが，末梢に流 れない，2 度は再疎通するが造影剂の末梢への流 れが遅い，3 度は造影遅延なく再開通した状態を

\section{表 1 血栓溶解療法の適応}

\section{絶対的適応 (ACC/AHA)}

発症 6 時間以内の心筋梗塞を示唆する胸痛と心電図 の2誘導以上における ST 上昇 $(>0.1 \mathrm{mV})$ を有する 70歳未満の患者

相対的適応 (ISFC/WHO)

発症 12 時間以内, 高齢者, 左脚ブロックで心電図所見 の判読できない例

指す。

\section{血栓溶解療法の適応と再開通の指標}

血栓溶解療法の適応は，現在のところ表 1 のよ うにまとめられるが，適応拡大の傾向にある。

冠動脈再開通の示標として臨床的には胸痛の速 やかな軽減, ST 低下, 再灌流性不整脈の出現, CK 酵素最大值までの時間的短縮などがある。CK 值は 再灌流によって不活性化を受け難くなり，むしろ 上昇するので CK 值による梗塞サイズの評価には 注意を要する．再灌流性不整脈が再灌流性傷害の 一指標かについては問題があるが，10２0\%の症 例にみられるとされる。室頻拍や心室細動の頻 度は $5 \%$ 未満と報告されている。

\section{合併症・副作用}

合併症としては出血が最重要である。大部分は 皮膚穿刺部出血で，他に消化管，尿路，歯肉出血 


\section{表 2 血栓溶解療法の禁忌}

絶対的禁忌 (ACC/AHA)

重篤な出血, 大動脈解離， 2 週間以内の外科手術・外

傷, 妊娠

相対的禁忌 (ISFC/WHO)

コントロールできていない重篤な高血圧, 血栓溶解薬 に対するアレルギー, 活動性の消化性潰皦

などがみられる．頭蓋内出血の頻度は我が国の調 查では $0.6 \%$ と高くないが, 臨床的には重要で, 種々 の薬剂，投与方法が検討されている。出血傾向の ある例は禁忌である。高龄，体格が小，女性，脳 血管障害の既往，高血圧，へパリンの使用でその リスクが大きくなる ${ }^{10)}$. 脳出血以外の主要な出血は 0.5 1\%に生じる.その他の合併症は表 2 の通り である，心原脳梗塞の頻度は減少しており，現在 1〜2\%となっている.

再灌流施行例では出血性梗塞がみられるが，そ の出血は通常梗塞領域内に限局し，梗塞を拡大し ないとされる。心破裂の頻度については再灌流ま での時間が遅延すると高くなるようである。

心原性ショック例は血栓溶解療法を行っても， 開通率は低く $(34 \%) ，$ 予後はあまり改善しない。 このようなショック例や 6 時間を過ぎた虚血進行 例の死亡率は $24 \%$ と, 通常の血栓溶解療法適応例 の3.9\%に比べ高く，むしろ PTCAの適応と考え られる。

\section{再 閉 塞}

血栓溶解薬は，溶解作用と同時に血栓形成促進 作用があり，また梗塞血管再開通後も多くの例に 高度の残存狭窄がみられ，再閉塞の割合は $5 \sim 25$ $\%$, 半減期の短い $\mathrm{t}-\mathrm{PA}$ では約 $14 \%$, 半減期が長く, 全身の線溶活性を高めるUK などでは平均 $8 \%$ と され，再閉塞により院内死亡率は $4.5 \%$ か $11 \%$ 一 と増加する。再閉塞は $90 \%$ 以上の残存狭窄例に多 く，アスピリンは $90 \%$ 未満の複雑病変における再 閉塞予防に有用とされる ${ }^{11)}$.

\section{新しい薬剮の開発}

我が国では mutant t-PA（E6010）が開発され, 半減期が 90 分と長く，2 分間の単回投与が可能で あり，30分の開通率が $62 \% ， 60$ 分で79\%と良好な 成績を示した，その他，staphylokinaseや，併用 薬としてトロンビンの特異的阻害薬 hirudin, その 合成ポリペプチドである hirulog, 血小板の糖蛋白 GPII b/IIIa 受容体をブロックする c7E3 などの開 発も進められている。

\section{血栓溶解療法と PTCA}

血栓溶解療法で再開通が得られない例の予後は 悪く,再開通不成功例において rescue PTCA は有 用である，才なわち，再疎通の得られた例にあ之 て emergent PTCA を施行する必要はなく ${ }^{12)}$ ，虚 血の自然再発ないし退院時の軽運動負荷で虚血が みられた時にのみ血行再建術を行ったTIMI-2 臨

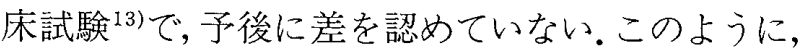
虚血がみられない限り薬剂療法に止める“watchful waiting”の有用性が各種の臨床試験で示されてい る。虚血が明らかな場合には，積極的に PTCAを 施行 (referrd PTCA) することにより再開通率は 96\%に達し，局所壁運動の改善，合併症や心事故 率の低下が可能となる。

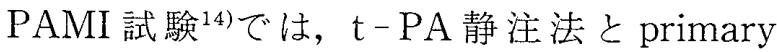
PTCA（direct PTCA）を比較し，院内および6 カ月後の再梗塞および死亡率において primary PTCA が有利としている。最近のメ夕分析 ${ }^{15)} に お ~$ いても，primary PTCA 群で脳卒中が有意に少な く，八イリスク患者における死亡率の低下が顕著 である.自施設での primary PTCA では，入院か ら再開通が得られるまでの時間は平均53分で，再 開通率は $90 \%$ であったが，発症より6 時間以内の 例では $96 \%$ （図 4)，入院中の再閉塞は $2.8 \%$ に過 ぎなかった.我が国の循環器専門施設では primary PTCA が急性心筋梗塞患者の約半数に行われてい るが, 米国では約10\%に施行されているに過ぎず, 一般的な治療にはなっていない。 
図 4 primary PTCA と血栓溶解 (CT) 群の再疎通率 (大阪赤十字病院)
全患者

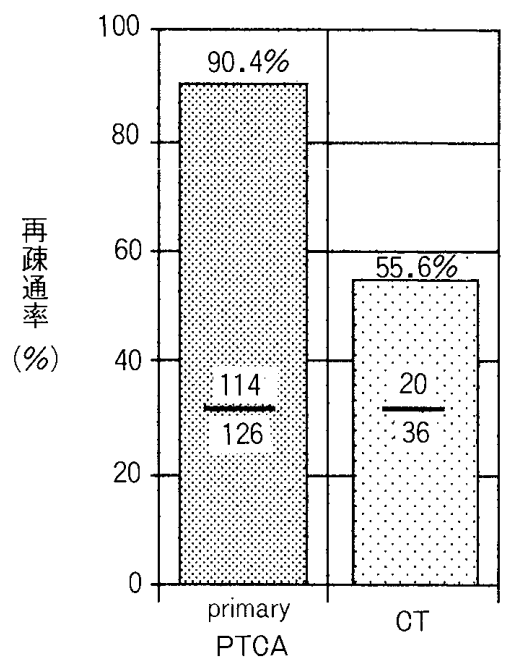

TIMI study criteria

を満たした患者群

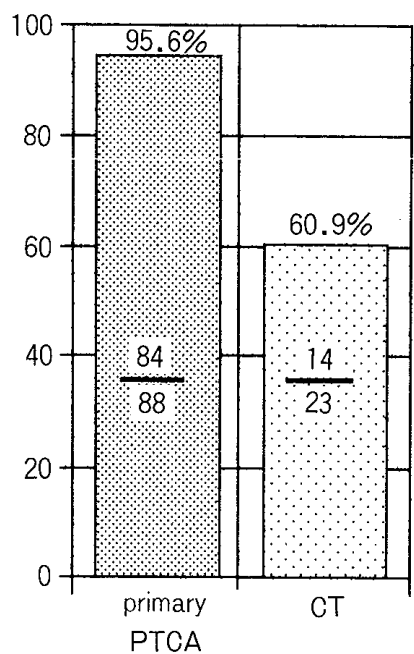

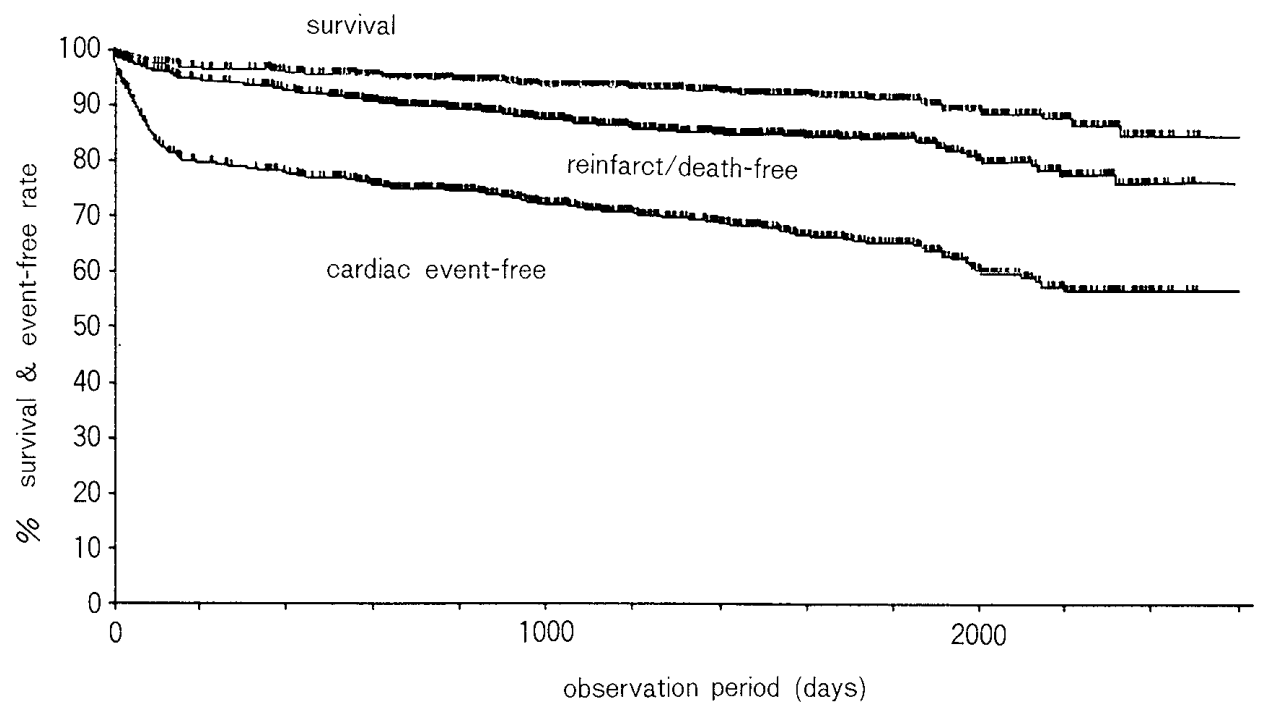

$\begin{array}{rrrrrr}\text { alive } & 1000 & 847 & 560 & 318 & 150 \\ \text { reinfarct/death-free } & 1000 & 830 & 545 & 301 & 138 \\ \text { event-free } & 1000 & 681 & 444 & 250 & 108\end{array}$

図 5 心筋梗塞1000例の予後曲線（Kaplan-Meier 法）

生存率，㧍よび再梗塞・死亡ないし心事故（死亡，再梗塞，再灌流療法施行）の非発生率。

\section{心筋梗塞の長期予後とその寄与因子}

心筋梗塞の長期子後も改善してきており，欧米 では 5 年死亡率が19～25\%，我が国では $12 \%$ と報 告されていたが，我々が1983〜1987年に施行した 心筋梗塞1000例の調査では，5年死亡率は $9 \%$ で
あった。心臟死の 5 年死亡率は $7.6 \%$ ，そのうちで 突然死は約半数の $3.4 \%$ 占めた（図 5 ).

死亡率は冠動脈罹患枝数によって異なり，0枝 および 1 枝病変では 4 5\%と低值であったが, 2 枝病変では $11 \% ， 3$ 枝病変では $23 \%$ と増加した。 平均39力月間の予後をみた試験では，その規定因 
子は左室機能および 4 週後の冠動脈開存と報告し ている ${ }^{16)}$. 我々の行った上記の研究では, 心臓死の 寄与因子として心不全, 駆出率, 冠動脈罹患枝数, 糖尿病および僧帽弁逆流が有意なものであった。 また心臓死, 再梗塞, 再灌流療法の施行を含めた 心事故率は年筒 $7 \%$ で，その寄与因子には冠動脈 罹患枝数, 梗塞後狭心症, 左主幹部病変が含まれ た。

突然死の寄与因子としては, ジギタリス, 硝酸 薬の投与, 左前下行枝の狭䇤度が有意であった。 なお，突然死は一般に発症 24 時間以内の急激な自 然死と定義され，その3/4 は虚血性心疾患が原因 と考えられている ${ }^{17)}$. 突然死は高齢者に多く ${ }^{18)}$, ま た男性で女性より 2 ～倍多い. 心筋梗塞にひき 続いて起こる突然死の病態因子として, 刺激の生 成ないし伝導障害, 左室機能障害, 残存虚血の存 在があげられ，梗塞部以下の遠位部虚血が重要で あるとされる ${ }^{19)}$. CASS の成績(2)によると, 左室駆 出率, 冠動脈罹患枝数, 性別, 心不全, 最大心拍 数，運動耐容能が予測因子となっている. Holter 心電図を用いた検討では, 無症候性の虚血性変化,

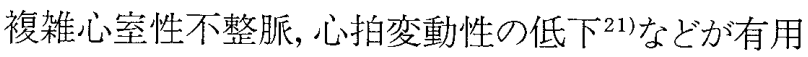
とされている。八ワイの日系米人男性を追跡した

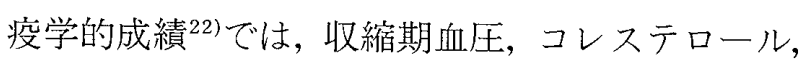
喫煙本数, 血糖, 心電困に拈ける左室肥大と冠動

Ma

1) The TIMI Study Group : Comparison of invasive and conservative strategies after treatment with intravenous tissue plasminogen activator in acute myocardial infarction: Results of the thrombolysis in myocardial infarction (TIMI) phase II trial. N Engl J Med $1989 ; 320$ : 618-627

2) Pfeffer M.A., Braunwald E., Moye L.A. et al. : The effect of captopril on mortality and morbidity in patients with left ventricular dysfunction following myocardial infarction: Results of the Survival and Ventricular Enlargement Trial. N Engl J Med 1992 ; 327 : 669-677

3 ) Kambara H., Kawai C. : Thrombolytic therapy in Japan: Urokinase infusion for acute myocar-
脈リスクファクターの重要性が指摘されている.

なお，薬物療法として $\beta$ 遮断薬には予防効果が

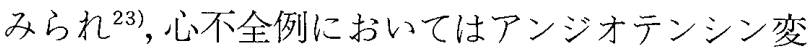
換酵素阻害薬の有用性が示されている.

\section{まとめ}

血栓溶解療法は，急性心筋梗塞の死亡率と予後 を改善する治療法として普及してきているが，限 界もある.例之ば, 血栓溶解療法を行っても約20２5 \%の症例では冠動脈の再開通が得られず，また再 開通が得られても，5〜25\%の例に急性冠閉塞が 生じ，安定した冠動脈の開存が維持できない。現 在のところ， primary PTCA を施行できれば，そ れが最善であろうが，施行できない場合には，血 栓溶解療法を実施して, 再灌流の有無を判定,

“watchful waiting”の方針で経過観察し，早い 時点でPTCA などの追加療法の必要性を検討する のがよい.

心筋梗塞後の予後は，かつて考之られていたよ りも改善して扝り，我が国での死亡率は年平均 1.6 \%と比較的良好である.PTCAなどによる残存虚 血の軽減でさらに予後の改善する可能性があるが, 死因として突然死が約半数を占め，その対策が重 要である。

献

dial infarction. In Tissue Plasminogen Activator in Thrombolytic Therapy (eds. Sobel B. E., Collen D., Grossbard E.B.). Marcel Dekker, New York 1987;223-235

4) Topol E.J., Califf R.M., Thrombolysis and Angioplasty in Myocardial Infarction-6 Study Group. et al. : A randomized trial of late reperfusion therapy for acute myocardial infarction. Circulation $1992 ; 85: 2090-2099$

5) Hirayama A., Adachi T., Asada S. et al. : Late reperfusion for acute myocardial infarction limits the dilatation of left ventricle without the reduction of infarct size. Circulation 1993; $88: 2565-2574$

$6)$ Ellis S.G., Debowey D., Bates E.R. et al. : Treat- 
ment of recurrent ischemia after thrombolysis and successful reperfusion acute myocardial infarction : Effect on in-hospital mortality and left ventricular function. J Am Coll Cardiol $1991 ; 17: 752-757$

7) The GUSTO Investigators: An international randomised trial comparing four thrombolytic strategies for acute myocardial infarction. N Engl J Med 1993 ; 329 : 673-682

8) Vogt A., von Essen R., Tebbe U. et al. : Impact of early perfusion status of the infarct related artery on short term mortality after thrombolysis for acute myocardial infarction: Retrospective analysis of four German multicenter studies. J Am Coll Cardiol 1993 ; 21 : 1391-1395

9) Belenkie I., Knudtson M.L., Roth D.L. et al. : Relation between flow grade after thrombolytic therapy and the effect of angioplasty on left ventricular function: A prospective randomized trial. Am Heart J 1991; 121 : 407-416

10) Maggioni A.P., Gruppo Italiano per lo Studio Della Sopravvivevza Nell'Infarto Miocardico II (GISSI-2)., International Study Group. et al. : The risk of stroke in patients with acute myocardial infarction after thrombolytic and antithrombotic treatment. N Engl J Med 1992 ; $327: 1-5$

11) Veen G., Meyer A., Verheugt F.W.A. et al.: Culprit lesion morphology and stenosis severity in the prediction of reocclusion after coronary thrombolysis: Angiographic results of the APRICOT study. J Am Coll Cardiol 1993 ; 22 : 1755-1762

12) The TIMI Study Group. : Comparison of invasive and conservative strategies after treatment with intravenous tissue plasminogen activator in acute myocardial infarction. N Engl J Med $1989 ; 320: 618-627$

13) Terrin M.L., Williams D.O., for the TIMI II. et al. : Two-and three-year results of the thrombolysis in myocardial infarction (TIMI) phase II clinical trial. J Am Coll Cardiol $1993 ; 22$ :
1763-1772

14) Grines C.L., Holmes D.R. et al. : A comparison immediate angioplasty with thrombolytic therapy for acute myocardial infarction. N Engl J Med $1993 ; 328: 673-679$

15) O'Neill W.W. et al.: Meta-analysis of the PAMI and Netherlands randomized trials of primary angioplasty versus thrombolytic therapy of acute myocardial infarction. Circulation $1993 ; 88$ (Suppl 4-2) : I-106

16) White H.D., Cross D.B., Elliott J.M. et al. : Long -term prognostic importance of patency of the infarct-related coronary artery after thrombolytic therapy for acute myocardial infarction. Circulation $1994 ; 89: 61-67$

17）徳留省悟，水沢郁文：大都市市民の突然死。診断 と治療 $1991 ； 79 ： 267-272$

18）神原啓文, 川村幸子，下田里美 他：突然死：京都 市における消防局救急出動記録の集計。心臓 $1993 ; 25: 254-260$

19) Schuster E.H., Bulkley B.H. : Early post infarction angina: Ischemia at a distance and ischemia in the infarct zone. N Engl J Med 1981; 305 : 1101-1105

20) Weiner D.A., Ryan T.J., McCabe C.H. et al.: Prognostic importance of a clinical profile and exercise test in medically treated patients with coronary artery disease. J Am Coll Cardiol $1984 ; 3: 772-779$

21) Kleiger R.E., Miller J.P., Bigger J.T. Jr. et al. : Decreased heart rate variavility and its association with increased mortality after acute myocardial infarction. Am J Cardiol 1987; 59 : 256-262

22) Kagan A., Yano K., Reed D.M. et al. : Prediction of sudden cardial death among HawaianJapanese men. Am J Epidemiol $1989 ; \mathbf{1 3 0}: 268$ $-277$

23) Olsson G., Ryden L.: Prevention of sudden death using $\beta$-blockers. Review of possible contributory actions. Circulation 1991;84: VI33-37 